\title{
USING OF NUMERICAL METHODS FOR CALCULATION THE EQUATION FOR CLUSTERS CONCENTRATIONS IN GASEOUS MATERIALS
}

\author{
Alexey Bublikov, Natalia Denisova, Tamara Segeda \\ D. Serikbayev East Kazakhstan State Technical University \\ Abstract: This article describes cluster model of gaseous materials and prospects of using the model. Equations set for the calculation of different sizes \\ clusters concentrations are presented. The authors produce numerical solution of the equation set. Results of the numerical solution are compared with \\ the results that derived from analytical solution. \\ Keywords: molecule, cluster, gas, cluster model, energetics, Newton's method, numerical methods

\section{WYKORZYSTANIE METOD NUMERYCZNYCH DO ROZWIĄZYWANIA UKLADU RÓWNAŃ KONCENTRACJI KLASTRÓW W MATERIAŁACH GAZOWYCH}

\begin{abstract}
Streszczenie. Ten artykuł zawiera opis modelu klastrowego materiałów gazowych i analiza perspektywy jego zastosowania. Przedstawiono układ równań do obliczania koncentracji klastrów różnych rozmiarów. Autorzy przedstawiaja rozwiąanie numeryczne danego układu. Wyniki rozwiązania numerycznego sa porównane z wynikami otrzymanymi metodami analitycznymi.
\end{abstract}

Słowa kluczowe: molekuła, klaster, gaz, model klastrowy, energetyka, metoda Newtona, metody numeryczne

At present, the success of innovation in heat and power engineering, like in any other sphere of up-to-date technologies, depends on the approach that uses preliminary calculations to a considerable degree. The more accurate is the model used as the basis for predictive computational and theoretical research, the more appropriate the assessment of expected outcome is. For example, in heat pump systems a heat pump power efficiency calculation is very important because these systems use substances under various values of pressure and temperature [6]. In this case, models of liquid and gaseous states in which properties of substances are explained by the movement and interaction of thermodynamic system's structural parts of are used for calculation. These structural parts can be not only molecules but also multi-molecular formations - clusters which preserve chemical properties of pure substances. It was found that models based only on the interactions of molecules cannot reflect all the peculiarities of complicated thermal process $[1,7]$. If we research a phase transition like evaporation or condensation or the process of equilibration in gas, the ideal gas model cannot be used even at pressure of about several millimeters of mercury. What is more, it is impossible to take measurements under all conditions which could occur in practice in heat and power engineering. Therefore, it is necessary to develop a theory which is based on a reliable model [2].

Specializing of the ideal gas law for describing systems which much more complicated than ideal gas lead to corrections in the ideal gas law which often don't have explicit physical meaning [10]. The description of equilibrium and non-equilibrium properties of dense gases is currently based on the ideal gas model which already takes into account that molecules of gases generate bound or quasi-bound states [1] and these clusters make their specific contribution in physical properties $[2,7]$. In such cluster model every gas should be considered like a multicomponent gas mixture; the number of these components and their concentration change with changing of macro parameters. The kinetic theory is used to describe the transfer processes, according to which the transfer coefficients are calculated by the formulae where gas mixture components are cluster subcomponents $[4,12,13]$.

Proportionality of a cluster's potential energy to the number of molecules this cluster contains is used as a primary principle in the cluster gas and liquid model and this proportionality gives the clusters' size distribution in the form:

$$
C_{g}^{(c)}=C_{1}^{(c)} \exp [-\beta(g-1)]
$$

where: $C_{g}^{(c)}$ is the numerical fraction of $g$-dimensional clusters (clusters which consist of $g$ molecules), $C_{1}^{(c)}$ is the numerical fraction of monomers (clusters with size 1 ), $\beta$ is the normalization factor, $g$ is the size of cluster (number of molecules in cluster).

Numerical fraction is used as the concentration of a cluster subcomponent through which additive parameters or a cluster mixture are expressed. The fraction is represented at a ratio of a cluster's numerical density to the numerical density of all clusters:

$$
C_{g}^{(c)} \equiv \frac{n_{g}}{\sum_{g=1}^{r} n_{g}}
$$

where: $n_{g}$ is the numerical density of $g$-dimensional clusters, $\sum_{g=1}^{r} n_{g}=n^{(c)}$ is the numerical density of all clusters, $r$ is the size of the largest accountable cluster in this problem.

Using this concentration average molar mass is expressed like [3]:

$$
\langle\mathrm{M}\rangle=\sum_{g=1}^{r} C_{g}^{(c)} \mathrm{M}_{g}
$$

where: $\mathrm{M}_{g}$ - molar mass of $g$-dimensional clusters, $\langle\mathrm{M}\rangle$ average molar mass of cluster mixture.

The most acceptable form of the equation of state in the cluster model is the equation which uses a compressibility factor $\mathrm{z}$ [3] by way of the deviation from the idealness factor:

$$
p=z n^{(n)} k T
$$

where: $n^{(n)}$ - numerical density of molecules.

The compressibility factor of cluster mixture is expressed through the concentration of cluster subcomponents [3]:

$$
z=\frac{1}{(1-b) \sum_{g=1}^{r} g C_{g}^{(c)}}
$$

What is more, the applied model medium principle also plays a significant role. According this principle, the particles pass through the sequence of locally equilibrium states: when they transit from one domain to the next one, they undergo maxwellization process, when they meet equilibrium particles and lose no longer belong to the previous domain [2]. The next step goes according to the same pattern; it makes the sequence of particles' the states additive chain of numbers which can be used for the description of gas processes. It allows to get the following set of equation $(1.6-1.8)$ for calculating cluster concentrations. 


$$
\begin{gathered}
C_{1}^{(c)}\left(1+\sum_{g=2}^{r} \exp [-\beta(g-1)]\right)-1=0 \\
C_{1}^{(c)} \sum_{g=1}^{r}\{g \exp [-\beta(g-1)]\}-\frac{\rho R T}{p \mathrm{M}_{1}(1-b)}=0 \\
C_{1}^{(c)} \exp [-\beta(g-1)]-C_{g}^{(c)}=0 \\
g=1 \div r .
\end{gathered}
$$

The set of equation takes into consideration a proper volume fraction of particles that is expressed in terms of effective collision diameter in the following general rule [1]:

$$
b=\frac{2}{3} n^{(n)} \pi \sigma^{3}
$$

where: $\sigma$ - effective molecules collision diameter.

After the transformation of this set of equation, through substitutions and algebraic transformations, we obtain a homogeneous nonlinear equation in (g-1) power. For example, for the calculation of cluster concentrations to the size five inclusive [11]:

$$
(2 B-1) x+(3 B-1) x^{2}+(4 B-1) x^{3}+(5 B-1) x^{4}+(B-1)=0,
$$

where: $e^{-\beta}=x, B$ factor is calculated in the following way:

$$
B=\frac{p M_{1}(1-b)}{\rho R T}
$$

where: $\rho$ is the density of gas, $T$ is the gas temperature, $R$ is the gas constant.

Methods of solution of nonlinear equations are divided into direct (analytical, exact) ones and iterative ones. Direct methods allow writing a solution as a certain proportion (formula). Thereby, the values of roots can be found by the formula in a finite number of arithmetic operations. Such methods are developed for trigonometric, logarithmic and elementary algebraic equations.

However, the equation that is derived in this problem cannot be solved by direct methods. It's impossible to get a solution in the form of formula which can be solved in a finite number of arithmetic operations even for an equation in the power more than four. In cases like that, it is necessary to use numerical methods which allow obtaining approximate values of the roots with any given accuracy.

The solution of nonlinear equations by numerical methods is divided into two steps [8]:

- the location of roots, that is finding of such segments on $\mathrm{X}$-axis which are the limits within of that there is only one root,

- the roots refining, that is calculating approximate values of roots within fixed precision.

The following methods of roots refining were examined: the bisection method, the secant method, the iteration method, Newton's method, Ridders' method [9]. After comparison of the results, Newton's method was chosen for the realization. On the basis of Newton's method the algorithm for finding concentrations of large-size (up to 100) clusters was developed. This algorithm is shown in the figure 1.

To test the algorithm and evaluate the approximate calculation results we used such experimental conditions for which there is a direct solution and cluster concentrations of size 5 in water vapor were obtained [11]. The comparison of the concentration values derived by numerical and analytic methods are shown in Table 1 .

The relative error with this method compared with analytical method is from $0.2 \%$ to $3 \%$ with a significant clusters concentration. So it makes it possible to use this method for the calculation of clusters concentrations of various sizes.

Obtaining a satisfactory results on the example data of water

\begin{tabular}{|c|c|c|c|c|c|c|c|c|c|c|c|c|}
\hline $\mathbf{P}, \mathbf{P a}$ & $\mathbf{T}, \mathbf{K}$ & $P, \mathrm{~kg} / \mathrm{m} 3$ & $\mathrm{C}_{1}$ & $\mathrm{C}_{2}$ & $\mathrm{C}_{3}$ & $\mathrm{C}_{4}$ & $\mathrm{C}_{5}$ & $\mathrm{C}_{6}$ & $\mathrm{C}_{7}$ & $\mathrm{C}_{8}$ & $\mathrm{C}_{9}$ & $\mathrm{C}_{10}$ \\
\hline \multicolumn{13}{|c|}{ R600 (Isobutane) } \\
\hline 124600 & 278,15 & 3,2858 & 0,951448 & 0,046195 & 0,002243 & 0,000109 & 0,000005 & 0,000000 & 0,000000 & 0,000000 & 0,000000 & 0,000000 \\
\hline \multicolumn{13}{|c|}{ R290 (Propane) } \\
\hline 530000 & 278,15 & 12,5 & 0,807060 & 0,155714 & 0,030044 & 0,005797 & 0,001118 & 0,000216 & 0,000042 & 0,000008 & 0,000002 & 0,000000 \\
\hline \multicolumn{13}{|c|}{ R717 (Ammonia) } \\
\hline 290800 & 263 & 2,394 & 0,939893 & 0,056494 & 0,003396 & 0,000204 & 0,000012 & 0,000001 & 0,000000 & 0,000000 & 0,000000 & 0,000000 \\
\hline 429400 & 273 & 3,46 & 0,923036 & 0,071040 & 0,005468 & 0,000421 & 0,000032 & 0,000002 & 0,000000 & 0,000000 & 0,000000 & 0,000000 \\
\hline 615000 & 283 & 4,87 & 0,903457 & 0,087223 & 0,008421 & 0,000813 & 0,000078 & 0,000008 & 0,000001 & 0,000000 & 0,000000 & 0,000000 \\
\hline 857400 & 293 & 6,697 & 0,881480 & 0,104473 & 0,012382 & 0,001468 & 0,000174 & 0,000021 & 0,000002 & 0,000000 & 0,000000 & 0,000000 \\
\hline 1167000 & 303 & 9,033 & 0,856320 & 0,123036 & 0,017678 & 0,002540 & 0,000365 & 0,000052 & 0,000008 & 0,000001 & 0,000000 & 0,000000 \\
\hline 1555000 & 313 & 11,983 & 0,828154 & 0,142315 & 0,024456 & 0,004203 & 0,000722 & 0,000124 & 0,000021 & 0,000004 & 0,000001 & 0,000000 \\
\hline
\end{tabular}
vapor the concentration of clusters were calculated for the following refrigerants: R600 (Isobutane), R290 (Propane), R717 (Ammonia). The results are presented in Table 2.

Table 1. Comparison of the derived concentration values

\begin{tabular}{|c|c|c|c|c|c|c|c|}
\hline Method & $\mathrm{P}, \mathrm{MPa}$ & $\mathrm{T}, \mathrm{K}$ & $\mathrm{C} 1$ & $\mathrm{C} 2$ & $\mathrm{C} 3$ & 0,01567 & 0,00211 \\
\hline Analytic & 8,922 & 758 & 0,86345 & 0,11631 & 0,01615 & 0,00028 \\
\hline Numerical & 8,922 & 758 & 0,86328 & 0,11806 & 0,00622 & 0,00221 \\
\hline Analytic & 9,02 & 798 & 0,91621 & 0,07546 & 0,00623 & 0,00051 \\
\hline Numerical & 9,02 & 798 & 0,91762 & 0,0756 & 0,01956 & 0,00004 \\
\hline Analytic & 8,824 & 713 & 0,846 & 0,12865 & 0,01957 & 0,000051 \\
\hline Numerical & 8,824 & 713 & 0,84816 & 0,12885 & 0,00645 & 0,00045 \\
\hline Analytic & 3,922 & 648 & 0,91456 & 0,07682 & 0,00045 \\
\hline Numerical & 3,922 & 648 & 0,91262 & 0,07975 & 0,00697 & 0,00061 \\
\hline Analytic & 1,108 & 563 & 0,98692 & 0,01252 & 0,00016 & 0,00005 \\
\hline Numerical & 1,108 & 563 & 0,98763 & 0,01222 & 0,00015 & 0 \\
\hline
\end{tabular}

Table 2. Concentration of clusters in refrigerants 


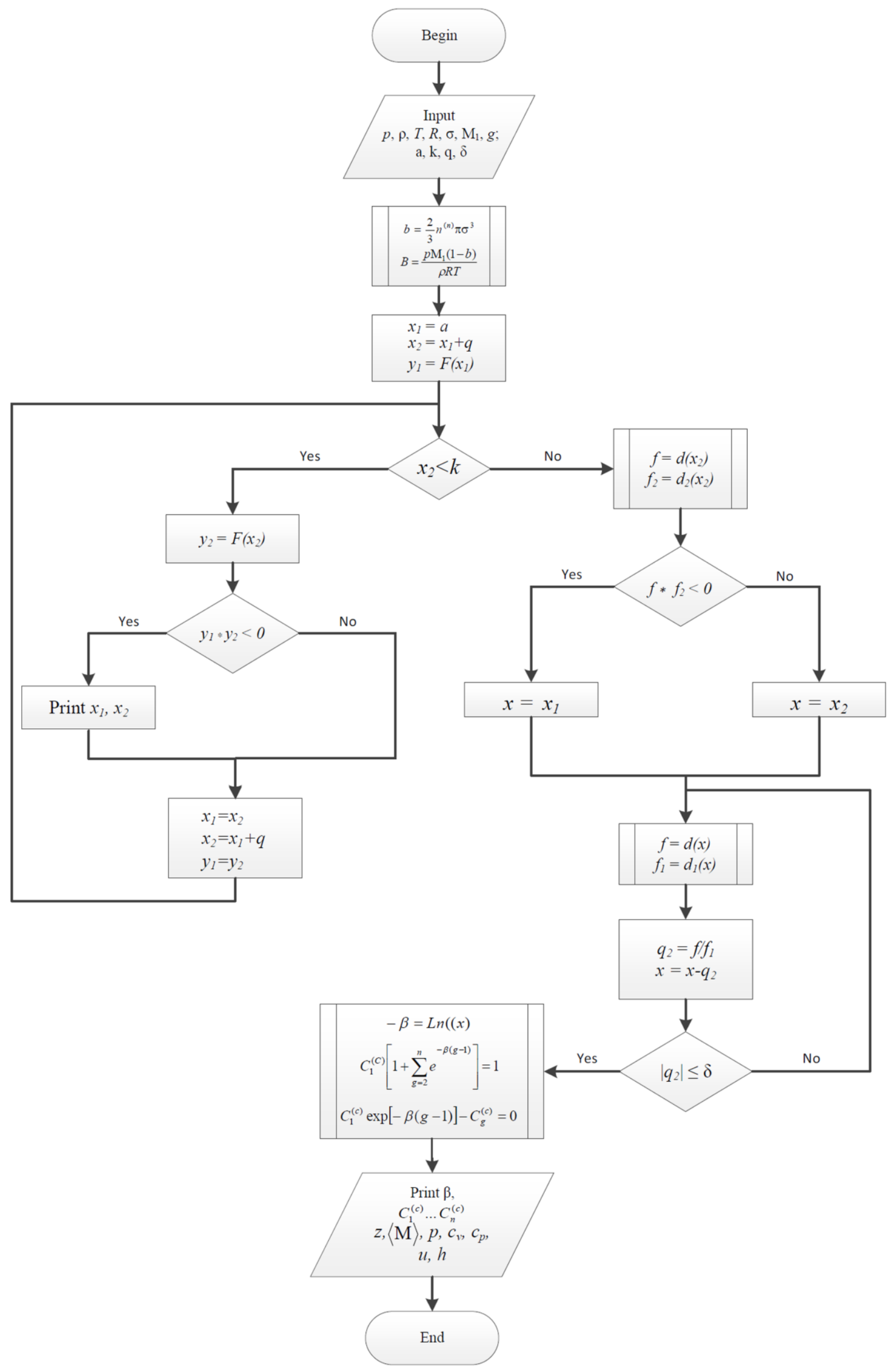




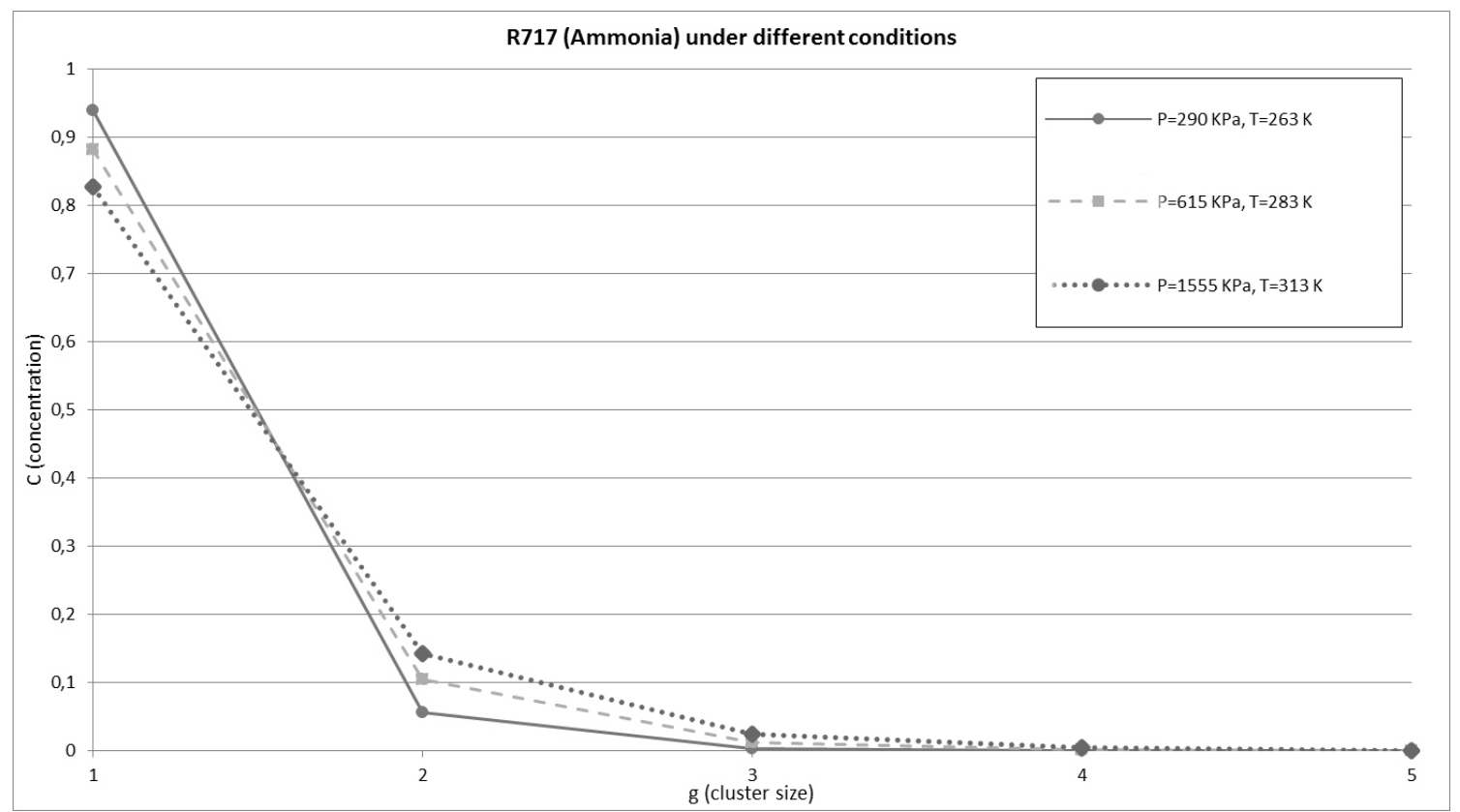

Fig. 2. The effect of conditions on the concentration of clusters

The effect of conditions on the concentration of clusters is shown in Figure 2, the example of the refrigerant R717 (Ammonia).

The parameters for the calculation of the concentration of clusters and calculated on this basis the characteristics of the gas mixture are considered experimental conditions and the characteristics of the mixture (gas). These include the following:

1) pressure of gas (mixture),

2) temperature of gas (mixture),

3) effective molecules collision diameter of gas (mixture),

4) density of gas (mixture),

5) molar mass of gas (mixture).

As intermediate outputs, which are also of interest to consider the problem as a whole, were used:

1) correction to their own volume of the molecules (formula 1.9);

2) $B$ factor (formula 1.10).

Goal data that is the output parameters are the totals:

1) compressibility factor of cluster mixture (formula 1.5),

2) enthalpy of molecular-cluster mixture,

3) relative internal efficiency.

For practical application of the method of calculating concentrations of clusters required software implementation and information support of the system. For software implementation was chosen the free integrated development environment Visual Studio Express 2012, developed by Microsoft. From the languages of this environment it was chosen programming language C \# 4.0. As a free database was chosen Microsoft SQL Server Express 2012.

\section{References}

[1] Girshfel'der Dzh., Kertiss Ch., Berd R.: Molekulyarnaya teoriya gazov i zhidkostei. M.: IL, 1961, s. 930.

[2] Kurlapov L.I.: Issledovanie protsessov perenosa v gazakh. Dep. v KazNIINTI, 21.05.90, № 4035, Ka, D90, Alma-Ata, 1990, s. 38 .

[3] Kurlapov L.I.: Klasternaya model' gaza ZhTF. T. 73, vyp. 2, 2003, s. $51-55$.

[4] Kurlapov L.I., D'yachenko E.A.: Kharakteristiki sostava klasternogo gaza. Dep. v KazgosINTI, 21.03.2001, № 8871, Ka01, Almaty, 2001, s. 13.

[5] Melikhov I.V., Dolgonosov B.M.: O klasternoi modeli zhidkosti, Zhurnal fizicheskoi khimii. T. LIII, vyp.7, 1979.

[6] Morozyuk T.V.: Teoriya kholodil'nykh mashin i teplovykh nasosov. Odessa: Studiya «Negotsiant», 2006, s.

[7] Nemukhin A.V.: Van-der-vaal'sovy klastery, Sorosovskii obrazovatel'nyi zhurnal. T. 7, № 1, 2001, s. 39 - 44.

[8] Polyanin A. D., Zaitsev V. F., Zhurov A. I.: Metody resheniya nelineinykh uravnenii matematicheskoi fiziki i mekhaniki. M.: Fizmatlit, 2005.
[9] Rashchikov V.I., Roshal' A.S.: Chislennye metody resheniya fizicheskikh zadach. SPb.: Lan', 2005.

[10] Rid R., Prausnits Dzh., Shervud T.: Svoistva gazov i zhidkostei: Spravochnoe posobie. L.: Khimiya, 1982, s. 592.

[11] Rodionova A.M.: Opredelenie termodinamicheskikh svoistv vodyanogo para s uchetom molekulyarno-klasternogo sostava: avtoref. ... mag. teploenergetiki. Ust'-Kamenogorsk, 2011, s. 16

[12] Rybin E.N., Valyukhov V.P., Kuptsov V.D.: Termodinamika nukleatsii peresyshchennogo para na molekulyarnykh yadrakh kondensatsii, ZhTF. T. 82 , vyp. 8,2012 , s. 22 - 27.

[13] Segeda T.A., Kurlapov L.I.: Osobennosti kineticheskikh effektov v molekulyarno-klasternykh smesyakh gazov, Materialy 5-i mezhdunarodnoi nauchnoi konf. «Khaos i struktury $\mathrm{v}$ nelineinykh sistemakh. Teoriya i eksperiment». Astana, 2006, Ch. 2, s. 203 - 206.

\section{Alexey Bublikov}

e-mail: bublikov.alexey@gmail.com

Master's Degree student «Computing and Software» of D. Serikbayev East Kazakhstan state technical university. The winner of the contest «Best degree work of 2012». The field of the scientific interests includes informational part of ecological monitoring of atmospheric air and cluster model of matters.

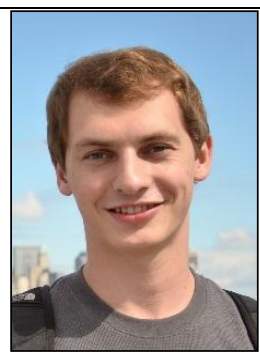

\section{Ph.D. Natalia Denisova}

e-mail: ndenisova@ektu.kz

Head of the Information Systems sub-department of D. Serikbayev East Kazakhstan state technical university. Defence of the thesis was in 2006. N. Denisova has published 81 publications in the last 5 years. She actively takes part in basic and applied researches in such spheres like education, ecology, using of mineral resources.

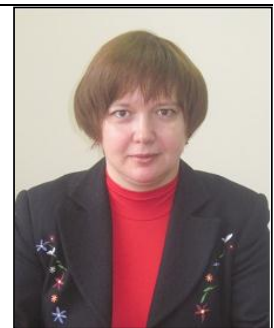

\section{Ph.D. Tamara Segeda}

e-mail: tsegeda@ektu.kz

Head of the Industrial Power Engineering sub-department of D. Serikbayev East Kazakhstan state technical university. Defence of the thesis was in 2006. The field of researches includes problems of energy processes optimization, renewable energy, cluster model of matters.

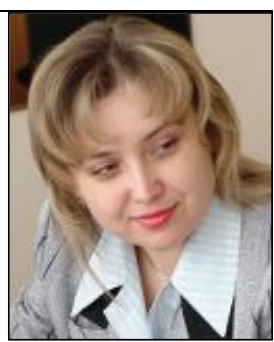

otrzymano/received: 19.04 .2013

przyjęto do druku/accepted: 12.11.2013 